DOI: 10.28995/2227-6165-2019-3-6-11

В данной статье исследуются пересечения генеративной антропологии и генеративного искусства в контексте постпостмодера и, в частности, постмиллениализма. Такое ключевое понятие генеративной антропологии как аттрактивный объект предлагается для утверждения, эффектом которого является рассмотрение постмилленниализма как объектно-ориентированной онтологии. В обоих случаях аттрактивный объект представляется деконструктивно, что приводит к тому, что он становится непредсказуемым, и в связи с этим субъект не участвует в оригинальном событии, таком как генеративный художественный перфоманс. Таким образом, любовь в антропологическом смысле преобладает над сексуальностью с ресентиментом, имманентно ей присущим, которая, следовательно, позволяет преодолеть как модерную жестокость, так и постмодерную виктимность. В этом отношении алгоритмизованная простота и минималистичность генеративного искусства обнаруживают себя в генеративной антропологии, возвращаясь к своему истоку.

Ключевъе слова: генеративная антропология, аттрактивный объект, генеративное искусство, непредсказуемость, непартисипация, перформатизм, минималистичность
Н.В. Загурская

доктор философских наук, доцент, ософии имени профессора И.Б. Шада zagurskaya@karazin.ua

\title{
GENERATIVE ANTHROPOLOGY AND GENERATIVE ART: UNPREDICTABILITY AND UNPARTICIPATION IN THE POST-MILLENNIARISM AS POST-POSTMODERN
}

\begin{abstract}
In this article traversals of generative anthropology and generative art are researched in the context of postpostmodern, and, in particular, post-millennialism. The crucial notion of generative anthropology as an attractive object suggested the approval that effected in postmillennialism being regarded an object-oriented ontology. In both cases an attractive object is deconstructively performated, which causes it to become unpredictibile and in relation with this a subject unparticipates in original event such as a generative art performance. Thus, love in anthropological sense prevails over sexuality with resentment that is immanently inherent to it and which, therefore, allows it to overcome modern cruelty as well as postmodern victimity. In this regard, generative art's algorithmized simplicity and minimalicity reveal themselves in generative anthropology by returning to their origin.
\end{abstract}

Keywords: generative anthropology, attractive object, generative art, unpredictibility, unparticipation, performatism, minimalicity

It is found that generative anthropology and generative art are similar in their striving to return to their source in order to revive an apathetic postmodern culture, and therefore the goals of this article is to track their intersection. However, realizing the desire to find their source, generative anthropology and generative art change various tactics; in particular, they strive to find the original attractive object and algorithm. The tasks of this article are to compare these tactics and consider the possibility of detecting an attractive object algorithm. In this way, archaic practices, nanotechnologies and contemporary art and also, conceptually, post-millennialism and digimodernism as trends of post-postmodern merge.

According to the generative anthropologist E. Gans meaning of the end of postmodern postmillennialism as a post-postmodern implies the end of a victimary thinking as a reflection of keys of the catastrophes of the 2oth century. He insists on the necessity of non-victimary dialogue to decrease the level of resentment and increase a level of love after the end of century, which surmises the end of both modern 
N.V. Zahurska Generative anthropology and generative art:

\section{unpredictability and unparticipation in the post-millenniarism as post-postmodern}

utopian expectations and postmodern apprehension of retributions and apathy, as well as and anesthesia connected with its. Postmodern resentment doesn't resist to capitalism and liberal democracy, which is why E. Gans refers to R. Girard to realize bloody and vital speculation. "Generative anthropology <...> is anything but bloodless speculation of the unknowable. Its quest for a fundamental understanding of the human is dedicated to the cause of promoting, in the face of resentment, the uniquely human union of appetite and intellect that we call love" [Gans, 'I love..., 1995]. Therefore, generative anthropology can be connected with Vital Materialism by Levy R. Brayant as a trend within Speculative Realism. However, in this case, the value of the object is emphasized, regardless of its attractiveness. Nevertheless, if Levy R. Brayant insists on the need to animate as a balance between what is human and what is natural in the broad sense of the word, then generative art reveals the possibility of balance in algorithmization as abstracting an object.

The novelty of this article appears in the consideration of an object in the interval between a certain degree of conservatism of generative anthropology, smoothed through deconstructive performatism and object-oriented ontology as a conceptualization of generative art. Such an approach seems to be fairly relevant in the context of post-postmodern eventuality, given the end of both public resentmentand victimary thinking. This also makes it possible to conceive of the human being itself as an object of generative art embedded in the private horizontal of love.

As R. Barthes notes, I-love-you in and of itself isn't a sentence; rather it is a holophrase and it seems, that this performative holophrase can assemble postmodern in-divided self. In this case, relationship between private and public sacrality are reversed and the distinction between tools and their use, langue and parole, and performativity and constative are marginalized. "The characteristic mode of the constative, what is designated is present independently of the sign that designates it. <...> Yet the modern sense of I love you is always latent, since to state the 'curse' of love is after all to affirm it, to participate in it" [Ibid.]. E. Gans insists that love is something like an eternal objectivation, which supposes that the object is greater than the subject. This corresponds to the comprehension of love as a revaluation of a certain object. If in the conditions of postmodern sexuality prevails, or at least a pluralistic approach to love or even to polyamory, then the post-postmodern event actualizes the intention for the authenticity of an event of love. However, E. Gans emphasizes the need for the tireless, above all linguistic, dialogical games, playing of partners difference. "In originary terms, love and resentment are relationships to difference. Resentment attacks (questions, suspects) difference because it sees it as invidious: the other's difference from me is a sign of his greater proximity to the center and its power, prestige, wealth, etc. Resentment sees only the 'vertical' component of difference, that which distinguishes between greater or less sacrality" [Gans, The Critique of Love, 1995]. These considerations are paradoxically relevant to generative art. The eternal and the superior object is made abstracted, but at the same time it is enlivened by the unpredictable game of digital forms.

In both generative anthropology and generative art cases, this means unpredictability, the degree of which accrues, multiplies and mutates or at least doesn't decline with a time. "For love remains alive only as long as it defies final explanations, as it retains an element of unpredictability. $<\ldots>$ coup de foudre, love at first sight, but the necessary moment of realization that one is indeed in love. $<\ldots>$ What we love in the Other is not mere variety, but a trajectory that cannot return to its earlier moments" [Gans, Toujoursl'amour, 1995]. Thus, one can connect the first event in A. Badiou's interpretation and the originary event, the residue of which appears as a langue representation. E. Gans supplements A. de Vigny's wish to love what you will never see twice, to love every moment as the possibility of the unpredictable resurrection of something vulnerable, which alone can cause tenderness.

Generative art implies of minimal forms constant and unpredictable resurrective playing in turn. Such a playing allows to bypass "the domination of the dominated by the dominator" [Gans, The Critique of Love, 1995]. This is why E. Gans dissociates both of them from the "constitutive hypocrisy of Romanticism" and sexuality itself with involved in feel of a dangerous and victimity from the one hand and guilt, culpability, jealousy and the rivalry from another hand. "To a Romantic the random is actually the fated, an opportunity to demonstrate the inner scene's independence from the calculations and influences of the outer scene. The random is freedom, even. Not this apparently automatic conversion of boredom and limited choice into 


\section{Н.В. Загурская Генеративная антропология и генеративное искусство:} непредсказуемость и непартисипация в постмиллениаризме как постпостмодерне rapid, deep 'love"' [Dennis, 2012, p. 9]. But in E. Gans meaning it's just love justifies sexuality and resistances to futile repetitiousness of pleasure, when the creation of forms happens in the space of a postmodern selfreferentiality. Therefore, instead of a randomness generative art leans rather toward an original algorithmized unpredictability.

R. van Oort attracts the attention of both J. Derrida and E. Gans investigations of origins. The Derridean deconstruction of "always-already" extends through "a fresh perspective on the function of language that goes beyond the metaphysical understanding of representation as a convenient tool for signifying a reality absent from the scene it appears on" [Oort, 1995, p. 4]. For this reason, it happens that instead is being appropriated in the moment of an undeferred linguistic presence an object is only designated. In addition, this moment occurs in-between the central object and the peripheral designators inside and outside, where, to quote J. Derrida, the outside iXs the inside. As compared to J. Derrida, E. Gans emphasizes, that deferral and presence are compatible and even synonymous as well as focuses on the original presence as a deferral of appropriative action. "It seeks to anthropologize the notion of presence itself, that is, to reestablish, on a nonmetaphysical basis, the understanding of presence as a uniquely human phenomenon" [Ibid., p. 8]. This iniquity reveals itself in playing of atomic and elementary forms like as in generative art performance both sensual and linguistic, which is creates a temporality of presence linguistic scene. "Language does not place sous rature the 'absolute presence' of the first sign; on the contrary, its system of differences extends this presence" [Gans, 2011, p. 184].

To a certain extent this considerations can be applied to art itself. "What we call art is the deliberate cultivation of the generative act. The artwork obliges us to experience over time an oscillation between perception of the representation and its meaningful interpretation that models the genesis of the originary sign" [Ibid., p. 205]. In the case of generative art it primarily meant sign-as-the-form in comparison with sign-as-the-sacred. An aesthetic emission of the sign implies that "signs' or representations cannot be divorced from the imaginary beings they generate in us" [Ibid., p. 201]. If this representation appears in a piece of meaningful artwork, the recipient feels this frisson and arrives at a state of oscillation. This is the gift of representation and the miracle of becoming-language. That's why E. Gans puts in circulation concept of anthropoethics as both the ethics and the poethics of a human being.

To make becoming last in generative art an algorithmized unpredicability of minimal and even banal forms like in kaleidoscope are used. A Hundred Thousand Billion Poems by R. Queneau or Scapes by B. Eno provide an example from music, that creates itself. E. Gans supposes, that just a minimal thinking and "generative anthropology may well be the first theory that claims maximal simplicity for a structure that it understands as paradoxical" [Gans, Simplicity or Complexity?, 1995]. P. Galanter takes into account meaning, claiming that generative art and art itself are possible because humans being are generative systems: "humans themselves are generative systems, and that, since humans ultimately create all art, all art is generative art $<\ldots>$ life as a literal embodiment of generative systems" [Galanter, 2016, p. 150]. Thus, one can argue the existence of sui generis evolutionary art, genetic algorithms playing of genotype in phenotype.

Thus, another crucial point of generative anthropology and generative art is unpredictable simplicity. Discreet Music by B. Eno, from which the notion is spread that generative music is synonymous with generative art as such, implicitly implies also discrete, simplified music and such play on words by itself is indicative and may serve as an example of generative literature. At the same time the emergent aesthetics of human beings complex adaptive systems implies simplicity as a simple brain creativity, which then reveals itself in complex and refined creativity, first and foremost in art creativity if by art we mean any human being creativity, the creation of human being arms. However if one considers evolutionary art and techné as its extension one will inevitable collides with a problem of an aesthetic evaluation of art, which eludes from human judgment. "Like art in general, generative art proceeds by a process of addition, not substitution" [Ibid., p. 175].

Thus, despite the participation art is widely practiced and discussed, pospostmodern sincerity is discovered in procedural and changeable unparticipative art and object-oriented anthropology. 


\section{N.V. Zahurska Generative anthropology and generative art:}

\section{unpredictability and unparticipation in the post-millenniarism as post-postmodern}

Nevertheless, when P. Galanter tries to put forth that art in the object, the system, the code he finds out that movement from objects to processes, from nouns to verbs and so on and beyond is realized. "It would embrace dynamism over formalism, celebrate the aesthetic of creation as an activity, and posit truth to process as being intrinsically beautiful" [Ibid., p. 174]. Asserting after S. LeWitt that a machine make the art as well is the art, P. Galanter furthermore attracts attention to a constant flux of bioart and nanotechnology as carrying on of evolutionary art. Therefore, generative art appears as a manner or way of art, "how the art is made" rather than in a content or concept and that's why it is unparticipative and autonomous. "Generative art refers to any art practice where the artist uses a system, such as a set of natural language rules, a computer program, a machine, or other procedural invention, which is set into motion with some degree of autonomy contributing to or resulting in a completed work of art" [Galanter, 2003].

Evolutionary art appears not only directly in nature, but also in tiling, fractals, L-systems for the preformation of plants or in Perlin noise for the preformation of non-living nature. Thus, one can speak about the agency of non-human or ever non-living being. In such a case simple, but aleatoric and chaosmic effective complexity as a mixture of order and disorder is inherent in both the brain, the mind and the weather. "Life to be more like a complex chaotic system and less like a simple random one $<\ldots\rangle$ artificial chaotic systems seem more like nature, and more like real life, than artificial random systems" [Ibid.]. Biological life is located between the order of crystals and the disorder of atmospheric gas and has been founded to be closer to atmospheric gas, providing becoming-Gas, to use R. Negarestani's concept. Non-human up to non-living agency is also close to the conceptions of agential realism put forward K. Barad or of hyperobject by T. Morton. However the most quantity of traversals has been founded between generative art's temporal and spatial non-linearity and human-nonhuman disconnection, which involve speculative posthumanism by D. Roden. Multiply simple nonhuman narratives induce small continuous changes and then to hyperobjective phased shift according the principal the whole is greater than the sum of the parts, which P. Galanter considers as an intrinsic to generative art.

Thereby generative art as generative anthropology refutes postmodern. If in the postmodern context form as beauty, knowledge and eventually subject is an arbitrary conventional human construct that in the post-postmodern context form is understood as an effect of natural processes, which happens in world generativity. As earlier in architecture T. Turner P. Galanter insists on the necessity of reanimation on faith as well as E. Gans stresses necessity to site in presence-as-truth. Thus, the features of this generativity are the autonomy and immediacy of the originary aesthetic experience: "experiential immediacy of the aesthetic moment of the originary scene there is a total separation between aesthetic experience and critical interpretation" [Nelson, 2009, p. 3].

S. Nelson attracts attention to such a post-postmodern property as a contraction of critical distance in originary immediacy, movement from apprehension to comprehension. Because romantic criticism and suspense reversed in postmodernity, the postromantic as post-postmodern aesthetics is involved in a proleptic temporality of immediacy, which unfolds now and after now. According to S. Nelson the prolepsis of the originary scene as a language paradox has been already achieved in the empty scene by S. Mallarmé. "This paradoxical doubling and surpassing is the 'end' of criticism, which, like Gans's 'end of culture,' has a double meaning as both 'terminus' and 'purpose.' Although criticism's prolepticity seems to foreclose any pronouncement of 'the end of criticism,' criticism's end is to be interminable. Its continual process of becoming, like becoming-human, necessitates a continual act of transcendence, and in transcending criticism, metacriticism brings us back to the originary aesthetic experience that is the guarantee of criticism's primacy as a human institution" [Ibid., p. 13].

R. Eshelman, on the contrary, stresses the performative component of originary operation of language: "originary scenes are in no way authentic; they are neither entirely natural nor are they prior to semiosis" [Eshelman, 2005-2006, p. 3]. He argues this by meaning that originary scene is always proceeds from the aborted gesture of appropriation and in a certain sense the Kantian intuitive and aesthetic grasp an object. But after E. Gans he agrees, that in Kantian aesthetics the value of knowledge is overestimated in comparison with nature because just an oscillation of coercive and painful limits of beauty make a beauty itself possible. 


\section{Н.В. Загурская Генеративная антропология и генеративное искусство:} непредсказуемость и непартисипация в постмиллениаризме как постпостмодерне

"Performatist aesthetics are in a certain sense 'Kant with a club': they bring back beauty, good, wholeness and a whole slew of other metaphysical propositions, but only under very special, singular conditions that a text forces us to accept on its own terms" [Ibid., p. 4]. Moreover, referring to different subjects from contemporary art he designates Kant with a sari, Kant with a cattle prod and so on. Thus, according to J.L. Nancy, the end of posthistory as the end of events and the cruelty of modern as well as victimity of postmodern mutates into post-postmodern originality. However, it is worth to recognize that postmodern implies and accepts a variance of its own tactics and post-postmodern in a certain sense stays postmodern, just as postmodern in a certaine case stays modern.

To this end, R. Eshelman attaches importance to that circumstance that "the new notion of performativity serves neither to foreground nor contextualize the subject, but rather to preserve it $<\ldots>$. For this reason the new subject always appears to the observer as reduced and 'solid,' as single- or simple minded and in a certain sense identical with the things it stands for" [Eshelman, 2000-2001, p. 1]. Recreating the subject in thing or object performs through object-bound signs and a human being may appear as being naïve or even idiotic a nomadic singularity. But this alone makes it possible to treat time, space, and causality as in Run Lola Run by T. Tykwer and the recipient may not ignore the involuntary act of believing in this performance in comparison with having postmodern faith in anything. "In contrast, in the new, performatist epoch there is a tendency to create chronotopes allowing a choice between possibilities or even repeated choices between possibilities. Contingency is now the prerogative of the subject and not of signs: the point is to preserve the integrity of the subject even under the most unfavorable conditions" [Ibid., p. 4].

R. Eshelman noted the following distinguished features of performatism: authenticity and radical renewal, simple subject, the present of paradoxical ostensivity, metaphysical optimism and phallicity as a performative activity and the framing of the vagina while at the same time the retraction of phallicity in love. To a certain degree, this is like Manni has saved Lola, or, more precisely, love has saved both of them by themselves. One can say, that films such as Run Lola Run, Cloud Atlas or Sense8 are an example of generative art and generative anthropology convergence in cinema in that there is a simple subject, almost an object is placed in a postmodern variative narrativity, but eventually it come to have ostensive authenticity. "Indeed, in the world of performatism the symbolic order of language and the chain of signifiers with its distracting puns play little or no role. The sign and/or language acts as a massive instrument in the service of the subject; decisive for the performatist work is the holistic, objectoriented force of the utterance and not the glissement of signifiers" [Ibid., p. 6].

To conclude is worth noting that in this article traversals of generative anthropology and generative art in their pursuit to attractive object origin are tracked down. The appeal just to an object allowed to sort these tactics with an object-oriented ontology with its simplicity and minimalicity. The consideration of the algorithmized simplicity of objectivation led to its approval of unparticipative anthropology and aesthetics. Such an approach contributed in turn to the approval of deconstructive performatism as a post-postmodern eventuality.

\section{REFERENCES}

1. Dennis, Ian. The Sexual Market: Three Romantic Moments. In: Anthropoetics: The Journal of Generative Anthropology, $X V I I$ (2), Spring 2012. Retrieved from http://anthropoetics.ucla.edu/ap1702/1702dennis/

2. Eshelman, Raoul.After Postmodernism: Performatism in Literature. In: Anthropoetics: The Journal of Generative Anthropology, XI (2), Fall 2005. Winter 2006. Retrieved from http://anthropoetics.ucla.edu/ap1102/performo5/

3. Eshelman, Raoul. Performatism, or the End of Postmodernism. In: Anthropoetics: The Journal of Generative Anthropology, $V I$ (2), Fall 200o. Winter 2001. Retrieved from http://anthropoetics.ucla.edu/apo602/perform/

4. Galanter, Philip. Generative art theory. In A Companion to Digital Art. Hoboken, 2016. Pp. 146-180.

[0] 5. Galanter, Philip. What is generative art? Complexity theory as a context for art theory. In: GA20o3 - 6th Generative Art Conference. Milan, 2003. Retrieved from https://www.generativeart.com/ 
N.V. Zahurska Generative anthropology and generative art: unpredictability and unparticipation in the post-millenniarism as post-postmodern

6. Gans, Eric. A New Way of Thinking: Generative Anthropology in Religion, Philosophy, Art. Aurora, 2011.

7. Gans, Eric. 'I love you'. In: Chronicles of Love and Resentment, 4, 1995.

Retrieved from http://anthropoetics.ucla.edu/views/vw4/

8. Gans, Eric. Simplicity or Complexity? In: Chronicles of Love and Resentment, 22, 1995.

Retrieved from http://anthropoetics.ucla.edu/views/vw22/

9. Gans, Eric. The Critique of Love. In: Chronicles of Love and Resentment, 102, 1997. Retrieved from http://anthropoetics.ucla.edu/views/vw102/

10. Gans, Eric. Toujours l'amour. In: Chronicles of Love and Resentment, 20, 1995. Retrieved from http://anthropoetics.ucla.edu/views/vw2o/

11. Nelson, Sylvie. The End of Criticism. In: Anthropoetics: The Journal of Generative Anthropology, XV (1), Fall 2009: GA Summer Conference Issue. Retrieved from http://anthropoetics.ucla.edu/ap1501/1501nelson/

12. Oort, Richard van Epistemology and Generative Theory: Derrida, Gans, and the Anthropological Subtext of Deconstruction. In: Anthropoetics: The Journal of Generative Anthropology I (1), Spring/Summer 1995.

Retrieved from http://anthropoetics.ucla.edu/apo101/vano/

\section{ЛИТЕРАТУРА}

1. Dennis, Ian. The Sexual Market: Three Romantic Moments // Anthropoetics: The Journal of Generative Anthropology, XVII (2), Spring 2012. Retrieved from http://anthropoetics.ucla.edu/ap1702/1702dennis/

2. Eshelman, Raoul. After Postmodernism: Performatism in Literature // Anthropoetics: The Journal of Generative Anthropology, XI (2), Fall 2005 / Winter 2006. Retrieved from http://anthropoetics.ucla.edu/ap1102/performo5/

3. Eshelman, Raoul. Performatism, or the End of Postmodernism // Anthropoetics: The Journal of Generative Anthropology, VI (2), Fall 2000 / Winter 2001. Retrieved from http://anthropoetics.ucla.edu/apo6o2/perform/

4. Galanter, Philip. Generative art theory // A Companion to Digital Art. Hoboken, 2016. P. 146-180.

5. Galanter, Philip. What is generative art? Complexity theory as a context for art theory // GA2003 - 6th Generative Art Conference. Milan, 2003. Retrieved from https://www.generativeart.com/

6. Gans, Eric. A New Way of Thinking: Generative Anthropology in Religion, Philosophy, Art. Aurora, 2011.

7. Gans, Eric. 'I love you' // Chronicles of Love and Resentment, 4, 1995.

Retrieved from http://anthropoetics.ucla.edu/views/vw4/

8. Gans, Eric. Simplicity or Complexity? // Chronicles of Love and Resentment, 22, 1995. Retrieved from http://anthropoetics.ucla.edu/views/vw22/

9. Gans, Eric. The Critique of Love // Chronicles of Love and Resentment, 102, 1997.

Retrieved from http://anthropoetics.ucla.edu/views/vw102/

10. Gans, Eric. Toujours l'amour // Chronicles of Love and Resentment, 20, 1995. Retrieved from http://anthropoetics.ucla.edu/views/vw2o/

11. Nelson, Sylvie. The End of Criticism // Anthropoetics: The Journal of Generative Anthropology, XV (1), Fall 2009: GA Summer Conference Issue. Retrieved from http://anthropoetics.ucla.edu/ap1501/1501nelson/

12. Oort, Richard van Epistemology and Generative Theory: Derrida, Gans, and the Anthropological Subtext of Deconstruction // Anthropoetics: The Journal of Generative Anthropology I (1), Spring/Summer 1995.

Retrieved from http://anthropoetics.ucla.edu/apo101/vano/ 